\title{
Effect of Nipping and Row Spacing on Crop Growth and Productivity of Medium Duration Pigeonpea
}

\author{
P. K. Panda* , P. M. Mohapatra, S. S. Bal, I. O. P. Mishra, \\ N. Senapati, R. K. Panigrahi and A. M. Prusti \\ Centre for Pulses Research, (OUAT), Berhampur-761001, India \\ *Corresponding author
}

\section{A B S T R A C T}

\begin{abstract}
Pigeonpea is generally grown in Kharif and its luxuriant growth very often create problem for spraying and other crop management. Nipping induces profuse branching, enlarge canopy and thus need more space for proper interception of solar radiation. Thus nipping and plant density has a close relation and thus it needs to be standardized. Keeping this in view a field experiment was conducted under AICRP on Pigeonpea during three consecutive years of kharif 2016-17, 2017-18 and 2018-19 at the Centre for Pulses Research, OUAT, Berhampur under rainfed condition to study the effect of nipping and spacing on crop growth and grain yield of medium duration pigeonpea. Pigeonpea variety Asha (ICPL 87119) was sown in Factorial Randomized Block Design with three replications. Altogether 12 treatment combinations comprised of two factors viz. Nipping 03(45DAS, 60DAS, No nipping), and row spacing-04 $(90 \mathrm{~cm}, 120 \mathrm{~cm}, 150 \mathrm{~cm}, 180$ $\mathrm{cm}$ )were taken. Row spacing significantly influence the crop yield and $120 \mathrm{~cm} \times 30 \mathrm{~cm}$ was found most suitable and recorded maximum yield ( $1602 \mathrm{~kg} / \mathrm{ha}$ ) as compared to other spacing. The variety Asha is spreading type and having profuse branching habit. The productivity was $11 \%$ higher than present recommendation $(90 \mathrm{cmX} 30 \mathrm{~cm})$ which may be due to higher number of fruiting branches per plant. However, further increasing in row spacing failed to compensate the reduction in production due to the lower plant density. Nipping at 45 DAS recorded more number of primary fruiting branch per plant (10.3), number of effective pod per plant (160.1) and the grain yield $(1416 \mathrm{~kg} / \mathrm{ha})$ as compared to nipping at $60 \mathrm{DAS}(1341 \mathrm{~kg} / \mathrm{ha})$ and no nipping $(1182 \mathrm{~kg} / \mathrm{ha})$. Interaction effect of nipping and spacing significantly influenced the crop yield and among the treatment combinations, row spacing $120 \mathrm{cmX} 30 \mathrm{~cm}+$ Nipping at 45DAS (T4) recorded maximum grain yield $(1798 \mathrm{~kg} / \mathrm{ha}$ ), which was significantly superior to all treatments except T5 (row spacing $120 \mathrm{cmX} 30 \mathrm{~cm}+$ Nipping at 60DAS). This treatment had also recorded maximum harvest index (0.34), highest net return (Rs.66948/-) with B: C ratio (3.23). It is concluded that medium duration spreading type pigeonpea with row spacing of $120 \mathrm{~cm}(30 \mathrm{~cm}$ intra-row plant to plant) and nipping at 45DAS may be recommended for rainfed kharif upland situation in Odisha, for obtaining maximum grain yield and net return.
\end{abstract}

\section{Introduction}

Pigeonpea is generally grown in Kharif and its luxuriant growth very often create problem for spraying and other crop management. Lower branches become non-productive due 
to shading effect. Nipping induces profuse branching, enlarge canopy and thus need more space for proper interception of solar radiation. Spacing is a function of plant canopy growth and in pigeonpea, factors like time of sowing, duration of variety, growing season (Kharif/pre-Rabi/Rabi), crop type (determinate/ indeterminate) and growth type (spreading/semi-spreading/compact) influence canopy growth besides soil fertility, soil moisture and crop management factors. Larger canopy require more space and smaller canopy prefer closer spacing for higher productivity (Panda et al., 2019).Thus nipping and plant density has a close relation and need to be standardized.

Further, spreading type medium duration pigeonpea has much potentiality for larger canopy growth especially when sown in time or early. Wider spacing with nipping may reduce seed rate, accommodate intercrops better and increase yield of pigeonpea through increase in number of primary fruiting branch. Per capita availability of pulses is gradually declining due to mismatch in the growth of human population and production of protein rich pulses and bridging this gap is essential to maintain self sufficiency in pulses production (Saxena, 2006).

Keeping this in view an experiment was laid out to studyi) the impact of nipping on branching and yield of pigeonpea, ii) to standardize the time of nipping in medium duration pigeonpea and iii) to study the interaction effect of nipping with spacing and find out the best combination for yield enhancement in pigeonpea.

\section{Materials and Methods}

Field experiments were conducted under AICRP on Pigeonpea during three consecutive years of Kharif 2016-17, 2017-18 and 2018-19 at Centre for Pulses Research,
OUAT, Berhampur under rainfed condition. Medium duration pigeonpea variety Asha (ICPL 87119) was own in Factorial Randomized Block Design with three replications. The experimental site comes under East \& South Eastern Coastal Plain zone of Odisha and Eastern Coastal Plains and Hills zone of India. Altogether 12 treatment combinations comprised of two factors viz. Nipping stage $-03\left(\mathrm{~N}_{1}\right.$ : $45 \mathrm{DAS}, \mathrm{N}_{2}$ : 60DAS, $\mathrm{N}_{3}$ : No nipping), and row spacing-04 $\left(\mathrm{S}_{1}: 90 \mathrm{~cm}, \mathrm{~S}_{2}: 120 \mathrm{~cm}, \mathrm{~S}_{3}: 150 \mathrm{~cm}, \mathrm{~S}_{4}: 180 \mathrm{~cm}\right)$ were taken. The crop received $698 \mathrm{~mm}$, $1303 \mathrm{~mm}$ and $1451 \mathrm{~mm}$ rain fall in 64,78 and 72 rainy days respectively during the crop season $\left(27^{\text {th }}\right.$ standard weekie $2^{\text {nd }}$ July to 4 th standard weekie $28^{\text {th }}$ January). The crop was sown during second fortnight of July each year $(18.07 .16,24.07 .17 \& 26.07 .18)$. The crop faced water logging due to $403 \mathrm{~mm}$ rainfall in two days ie. $6^{\text {th }} \& 7^{\text {th }}$ Aug.2018 and severe cyclonic storm (TITLI) on 11.10.2018, but escaped from damage due to proper drainage facility.

The soil was sandy loam with $\mathrm{pH} 6.2$ (acidic), low Organic Carbon (1.95g/kg soil), low available $\mathrm{N}(220 \mathrm{~kg} / \mathrm{ha})$, medium available phosphorus $(21.67 \mathrm{~kg} / \mathrm{ha})$, medium available potassium (156kg/ha) and EC - $0.007 \mathrm{dS} / \mathrm{m}$ (Normal). Recommended package of practice, nutrient management, weed management and plant protection measures were followed.

Observations on plant height, yield attributes, grain yield, bhusa yield, stick yield were taken at harvest and analysed as per statistical procedure described by Panse and Sukhatme (1985). Derived data like total dry matter production (TDMP) and harvesting index (HI) were also calculated. Economics of the treatment combinations including gross return, net return and $\mathrm{B}$ : $\mathrm{C}$ ratio were calculated and compared for economic feasibility. 


\section{Results and Discussion}

\section{Plant height}

The pooled data of three years (2016-19) on plant height presented in table- 1 revealed that, in medium duration pigeonpea (cv. Asha), plant height was significantly influenced by nipping. Tallest plant $(191.6 \mathrm{~cm})$ was always associated with no nipping $\left(\mathrm{N}_{3}\right)$ and shortest plants $(152.4 \mathrm{~cm})$ with nipping at 60DAS $\left(\mathrm{N}_{2}\right)$. No significant difference in plant height was observed due to different row spacing. However, interaction effect of spacing and nipping was found significant and maximum plant height $(193.8 \mathrm{~cm})$ was recorded with $\mathrm{S}_{2} \mathrm{~N}_{3}(120 \mathrm{~cm}$ X $30 \mathrm{~cm}$ with no nipping) .

\section{Yield attributes}

Various yield attributes of pigeonpea cv. Asha were taken at harvest and placed in table- 1 . Number of primary fruiting branches showed significant variation due to both varying row spacing and nipping. The variety Asha is spreading type and having profuse branching habit. Maximum branches (9.8) were recorded with both $120 \mathrm{~cm}$ and $150 \mathrm{~cm}$ row spacing. Nipping at 45DAS produce profuse branches per plant (10.3), which was significantly superior to nipping at 60 DAS (9.2) and 20\% higher than no nipping (8.6). Interaction effect also showed significant variation and the maximum number of fruiting branches per plant (11.18) was recorded with $\mathrm{S}_{2} \mathrm{~N}_{1}(120 \mathrm{~cm}$ $\mathrm{X} 30 \mathrm{~cm}$ with nipping at 45DAS). The number of effective pods / plant was also followed the same trend and the maximum number of pods/ plant was obtained from $120 \mathrm{~cm}$ row spacing (154.7), nipping at 45DAS (160.1) and combination of both (173.6). Number of seeds/pod did not differ significantly either due to row spacing or due to nipping. The interaction of both components had also no effect on number of seeds/ pod .

\section{Yield}

The pooled data of three years (2016-19) depicted in table -1 revealed that row spacing, nipping and their interaction significantly influence the grain yield in medium duration pigeonpea (cv. Asha), Row spacing of $120 \mathrm{~cm}$ $X 30 \mathrm{~cm}$ was found most suitable and recorded highest yield (1602 kg/ha), which is $11 \%$ higher than present recommendation $(90 \mathrm{cmX} 30 \mathrm{~cm}$. However further increasing in row spacing failed to compensate the reduction in grain yield due to lower plant density (Table-1). Sujata and Babalad (2018) obtained maximum yield of $2662 \mathrm{~kg} / \mathrm{ha}$ from transplanted pigeonpea with spacing $120 \mathrm{~cm} X 60 \mathrm{~cm}$. Nipping at 45 DAS recorded significantly higher grain yield (1416kg/ha) than that obtained from plots without nipping (1182kg/ha), but at par with nipping at 60 DAS(1341kg/ha). Desmukh (2018) obtained similar result at Vasantrao Naik Marathwada Agricultural University, Parvani. On an average nipping enhance grain yield of pigeonpea to a tune of $16 \%$ probably due to increase in primary fruiting branches. Significant variations among treatments were observed due to interaction effect of row spacing and nipping. Among the treatment combinations, row spacing of $120 \mathrm{~cm}$ X $30 \mathrm{~cm}$ +Nipping at 45DAS (T4) recorded maximum grain yield $(1798 \mathrm{~kg} / \mathrm{ha})$ which was at par $(1667 \mathrm{~kg} / \mathrm{ha}$ ) with T5 (row spacing $120 \mathrm{cmX} 30 \mathrm{~cm}+$ Nipping at 60DAS) and significantly superior to all others. Bhusa yield followed the similar trend as that of grain yield (Table-1) and the maximum (1026kg/ha) was obtained from row spacing of $120 \mathrm{cmX} 30 \mathrm{~cm}+$ Nipping at 45DAS (T4). Maximum stick yield $(2436 \mathrm{~kg} / \mathrm{ha})$ was however obtained from closest spacing $(90 \mathrm{~cm}$ $\mathrm{X} 30 \mathrm{~cm})$ probably due to more plant density. Stick yield did not differ significantly due to nipping. Nevertheless, the interaction effect of row spacing and nipping had significant influence on stick yield and the maximum 
(2491kg/ha) being recorded with T3 (row spacing of $90 \mathrm{~cm}$ X $30 \mathrm{~cm}+$ No Nipping) closely followed by $\mathrm{T} 4$ (row spacing of $120 \mathrm{~cm} X 30 \mathrm{~cm}+$ Nipping at 45DAS). Nipping did not influence total dry matter production (TDMP) significantly. But, TDMP differ significantly due to row spacing and $\mathrm{S} 2$

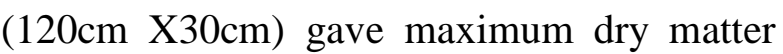
$(4983 \mathrm{~kg} / \mathrm{ha})$. Conspicuous variation in total dry matter production in pigeonpea was found due to interaction effect and the maximum $(5292 \mathrm{~kg} / \mathrm{ha}$ ) being recorded with T4 (row spacing of $120 \mathrm{cmX} 30 \mathrm{~cm}+$ Nipping at 45DAS).

Table.1 Effect of nipping \&row spacing on crop growth, yield attributes, yield and harvest index of medium duration pigeonpea (cv. ASHA).(pooled 2016-19)

\begin{tabular}{|c|c|c|c|c|c|c|c|c|c|}
\hline Treatment & $\begin{array}{l}\text { Pl.ht. } \\
\text { (cm) }\end{array}$ & br/plant & Pod/plant & seed/pod & $\begin{array}{c}\text { Grain } \\
\text { yield } \\
(\mathbf{k g} / \mathbf{h a})\end{array}$ & $\begin{array}{c}\text { Stick } \\
\text { yield } \\
\text { (kg/ha) }\end{array}$ & $\begin{array}{c}\text { Bhusa } \\
\text { yield } \\
\text { (kg/ha) }\end{array}$ & $\begin{array}{l}\text { TDMP } \\
\text { (kg/ha) }\end{array}$ & HI \\
\hline $\mathbf{S}_{1}$ & 171.5 & 8.2 & 117.4 & 3.4 & 1437 & 2436 & 896 & 4770 & 0.30 \\
\hline $\mathbf{S}_{2}$ & 171.8 & 9.8 & 154.7 & 3.5 & 1602 & 2419 & 963 & 4983 & 0.32 \\
\hline$S_{3}$ & 167.5 & 9.8 & 154.0 & 3.5 & 1259 & 2228 & 809 & 4296 & 0.29 \\
\hline $\mathbf{S}_{4}$ & 168.4 & 9.7 & 150.8 & 3.6 & 953 & 1744 & 696 & 3393 & 0.28 \\
\hline $\operatorname{SEm}( \pm)$ & NS & 0.41 & 6.56 & NS & 53.44 & 85.59 & 31.23 & 173.08 & \\
\hline $\operatorname{CD}(5 \%)$ & & 1.21 & 19.24 & & 156.73 & 251.04 & 91.59 & 507.67 & \\
\hline$N_{1}$ & 165.5 & 10.3 & 160.1 & 3.6 & 1416 & 2249 & 877 & 4541 & 0.31 \\
\hline $\mathbf{N}_{2}$ & 152.4 & 9.2 & 147.4 & 3.5 & 1341 & 2202 & 853 & 4396 & 0.30 \\
\hline $\mathbf{N}_{3}$ & 191.6 & 8.6 & 125.2 & 3.5 & 1182 & 2169 & 793 & 4144 & 0.28 \\
\hline $\operatorname{SEm}( \pm)$ & 5.24 & 0.36 & 5.66 & NS & 46.07 & NS & 26.92 & NS & \\
\hline $\operatorname{CD}(5 \%)$ & 15.36 & 1.04 & 16.59 & & 135.13 & & 78.96 & & \\
\hline $\mathbf{S}_{1} \mathbf{N}_{1}$ & 167.3 & 9.13 & 127.3 & 3.43 & 1523 & 2459 & 936 & 4918 & 0.31 \\
\hline $\mathbf{S}_{1} \mathbf{N}_{2}$ & 154.9 & 8.07 & 119.8 & 3.4 & 1410 & 2358 & 884 & 4652 & 0.30 \\
\hline $\mathbf{S}_{1} \mathbf{N}_{3}$ & 192.2 & 7.32 & 105.2 & 3.4 & 1379 & 2491 & 869 & 4739 & 0.29 \\
\hline $\mathbf{S}_{2} \mathbf{N}_{1}$ & 167.5 & 11.18 & 173.6 & 3.6 & 1798 & 2468 & 1026 & 5292 & 0.34 \\
\hline $\mathbf{S}_{2} \mathbf{N}_{2}$ & 154.1 & 9.77 & 161.1 & 3.53 & 1667 & 2452 & 998 & 5117 & 0.33 \\
\hline $\mathbf{S}_{2} \mathbf{N}_{3}$ & 193.8 & 8.52 & 129.3 & 3.5 & 1341 & 2336 & 864 & 4541 & 0.30 \\
\hline $\mathbf{S}_{3} \mathbf{N}_{1}$ & 162.9 & 10.87 & 174.6 & 3.57 & 1353 & 2285 & 852 & 4490 & 0.30 \\
\hline $\mathbf{S}_{3} \mathbf{N}_{2}$ & 150.8 & 9.32 & 153.8 & 3.53 & 1287 & 2263 & 822 & 4372 & 0.29 \\
\hline $\mathbf{S}_{\mathbf{3}} \mathbf{N}_{\mathbf{3}}$ & 188.9 & 9.12 & 133.5 & 3.47 & 1137 & 2136 & 752 & 4025 & 0.28 \\
\hline $\mathbf{S}_{4} \mathbf{N}_{1}$ & 164.1 & 10.14 & 164.8 & 3.6 & 990 & 1782 & 693 & 3465 & 0.29 \\
\hline $\mathbf{S}_{4} \mathbf{N}_{2}$ & 149.6 & 9.45 & 154.9 & 3.57 & 998 & 1736 & 708 & 3442 & 0.29 \\
\hline $\mathbf{S}_{4} \mathbf{N}_{3}$ & 191.6 & 9.38 & 132.7 & 3.57 & 871 & 1714 & 687 & 3272 & 0.27 \\
\hline $\operatorname{SEm}( \pm)$ & 10.47 & 0.71 & 11.31 & NS & 92.13 & 147.57 & 53.84 & 298.42 & \\
\hline $\operatorname{CD}(5 \%)$ & 30.71 & 2.08 & 33.17 & & 270.20 & 432.83 & 157.92 & 875.28 & \\
\hline $\mathrm{CV}(\%)$ & 11.39 & 13.68 & 14.25 & & 13.81 & 14.32 & 12.67 & 13.43 & \\
\hline
\end{tabular}


Table.2 Effect of nipping and row spacing on productivity and economics of medium duration pigeonpea (cv. ASHA). (average data of three years, 2016-19)

\begin{tabular}{|c|c|c|c|c|c|}
\hline Treatment combination & $\begin{array}{c}\text { Yield } \\
\text { (kg/ha) }\end{array}$ & $\begin{array}{c}\text { Gross } \\
\text { Return } \\
\text { (Rs) }\end{array}$ & $\begin{array}{l}\text { Cost of } \\
\text { production } \\
\quad(\mathbf{R s})\end{array}$ & $\begin{array}{c}\text { Net } \\
\text { Return } \\
\text { (Rs) }\end{array}$ & $\begin{array}{c}\text { B:C } \\
\text { Ratio }\end{array}$ \\
\hline$T 1: S_{1} N_{1}-90 X 30 \mathrm{~cm}+$ Nipping at 45DAS & 1523 & 82120 & 30500 & 51620 & 2.69 \\
\hline $\mathrm{T} 2: \mathrm{S}_{1} \mathrm{~N}_{2}-90 \mathrm{X} 30 \mathrm{~cm}+\mathrm{Nipping}$ at 60DAS & 1410 & 76027 & 30500 & 45527 & 2.49 \\
\hline T3: $\mathrm{S}_{1} \mathrm{~N}_{3}-90 \times 30 \mathrm{~cm}+$ No Nipping & 1379 & 74356 & 29500 & 44856 & 2.52 \\
\hline T4: $S_{2} N_{1}-120 X 30 \mathrm{~cm}+$ Nipping at 45DAS & 1798 & 96948 & 30000 & 66948 & 3.23 \\
\hline 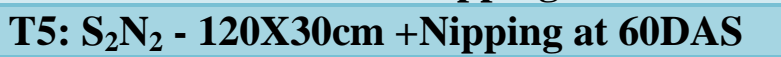 & 1667 & 89885 & 30000 & 59885 & 3.00 \\
\hline T6: $S_{2} N_{3}-120 X 30 \mathrm{~cm}+$ No Nipping & 1341 & 72307 & 29000 & 43307 & 2.49 \\
\hline 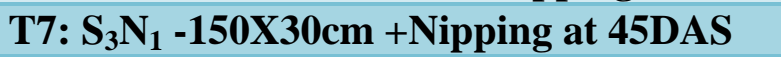 & 1353 & 72954 & 29750 & 43204 & 2.45 \\
\hline T8: $\mathrm{S}_{3} \mathrm{~N}_{2}-150 \times 30 \mathrm{~cm}+\mathrm{Nipping}$ at 60DAS & 1287 & 69395 & 29750 & 39645 & 2.33 \\
\hline T9: $S_{3} N_{3}-150 X 30 \mathrm{~cm}+$ No Nipping & 1137 & 61307 & 28750 & 32557 & 2.13 \\
\hline T10: $S_{4} N_{1}-180 X 30 \mathrm{~cm}+$ Nipping at 45DAS & 990 & 53381 & 29750 & 23631 & 1.79 \\
\hline T11: $\mathrm{S}_{4} \mathrm{~N}_{2}-180 \times 30 \mathrm{~cm}+$ Nipping at 60DAS & 998 & 53812 & 29750 & 24062 & 1.81 \\
\hline T12: $\mathrm{S}_{4} \mathrm{~N}_{3}-180 X 30 \mathrm{~cm}+$ No Nipping & 871 & 46964 & 28500 & 18464 & 1.65 \\
\hline
\end{tabular}

NB:Cost of pigeonpea grain was Rs.50.50/kg(2016-17), Rs.54.50 / $\mathrm{kg}(2017-18) \&$ Rs.56.75/kg (20!8-19)respectively as per MSPand average priceof three years was Rs. $53.92 / \mathrm{kg}$.

\section{Harvest index}

Harvest Index was calculated on proportion of grain yield to biological yield i.e. total dry matter production of above ground parts to find out the dry matter partitioning of pigeonpea to grain as influenced by row spacing and nipping (Table-1). This can be used as a measure of reproductive efficiency. Among row spacing's, the maximum value (0.32) was computed with $\mathrm{S} 2(120 \mathrm{~cm} \mathrm{X}$ $30 \mathrm{~cm}$ ) and among nipping, N1 (Nipping at 45DAS) found superior (0.31). Considering the treatment combination, the maximum harvest index (0.34) was computed with T4 (row spacing of $120 \mathrm{cmX} 30 \mathrm{~cm}+$ Nipping at 45DAS) (Table-1).

\section{Economics}

Economics for each treatment combination was computed to find out economic feasibility of the recommended practice and presented in Table-2. The gross return was calculated from average grain yield of pigeonpea over three years (2016-19) multiplied with average seed rate of pigeonpea grain as per MSP. The cost of cultivation was also computed as per average value of three years. Average wages for nipping @ Rs. 1000/- per hectare were added in nipping treatments and lowering of seed rate due to larger spacing ( $\mathrm{S} 1: 20 \mathrm{~kg} / \mathrm{ha}$, $\mathrm{S} 2: 15 \mathrm{~kg} / \mathrm{ha}, \mathrm{S} 312.5 \mathrm{~kg} / \mathrm{ha}, \mathrm{S} 4: 10 \mathrm{~kg} / \mathrm{ha}$ ) were also considered and deducted from treatments with wider spacing @ Rs. 100/kg seed. The highest gross return (Rs. 96,948/ha), net return (Rs66, 948/ha) and B: C ratio (3.23) was obtained from T4 (row spacing of $120 \mathrm{cmX} 30 \mathrm{~cm}+$ Nipping at 45DAS) indicating its more economic feasibility. Profit decreased with wider row spacing beyond $120 \mathrm{~cm}$ and the lowest net return (Rs.18, 464/ha) and B: C ratio (1.65) was recorded with T12 (row spacing of $180 \mathrm{~cm} \mathrm{X}$ $30 \mathrm{~cm}+$ No Nipping).

In conclusion the East \& South Eastern Coastal Plain zone of Odisha, under kharif rainfed upland condition, medium duration spreading type pigeonpea (cv. Asha) with row 
spacing of $120 \mathrm{~cm}(30 \mathrm{~cm}$ intra-row plant to plant) along with nipping at 45DAS may be recommended for obtaining maximum grain yield, net return and $\mathrm{B}$ : $\mathrm{C}$ ratio.

\section{References}

Deshmukh, R.R. 2018. Effect of nipping and spacing on growth and yield of pigeonpea. M.Sc. (Ag) Thesis, Vasantrao Naik Marathwada Agricultural University, Parvani. pp: 1118.

Panda, P.K., Mahapatra, P.M., Kar, A., Panigrahi, R.K., Bal, S. S., Mishra, I.O.P., and Prusti, A.M. 2019. Performance of pigeonpea genotypes with varying planting geometry under irrigated rabi condition. Indian Agriculturist. 63(2): 81-86.

Panse, V.G., and Sukhatme, P. V. 1985. Statistical method for Agricultural Workers, $4^{\text {th }}$ edition, ICAR, New Delhi, pp. 327-340.

Saxena, K. B.2006. Seed Production System in Pigeonpea. ICRISAT, Information Bulletin. 74:76

Sujata, H. T., and Babalad, H.B.2018. Effect of planting method, geometry and intercrops on growth and productivity of pigeonpea in pigeonpea based cropping system. Journal of pharmacognosy and phytochemistry. 7(6): 26-30.

\section{How to cite this article:}

Panda, P. K., P. M. Mohapatra, S. S. Bal, I. O. P. Mishra, N. Senapati, R. K. Panigrahi and Prusti, A. M. 2020. Effect of Nipping and Row Spacing on Crop Growth and Productivity of Medium Duration Pigeonpea. Int.J.Curr.Microbiol.App.Sci. 9(08): 1832-1837. doi: https://doi.org/10.20546/ijcmas.2020.908.209 